\title{
Mediation Starring role of Student's Satisfaction in Open Distance Learning in Sri Lanka
}

\author{
M. J. Renuka Perera \\ The Open University of Sri Lanka \\ Nalin Abeysekera \\ The Open University of Sri Lanka
}

\begin{abstract}
In the education environment Students' Perceived Service Quality (SQ), Satisfaction (SAT) and students' favourable or unfavourable behaviour can be considered as significant factors of students' retention and accomplishment of registered programmes with in their stipulated time. The Open Distance Learning (ODL) is widely spread and established flexible pedagogy system with the fast-growing technological enhancement. Year by Year the student population has been drastically increased but completion rate has uncovered a very challenging situation. The service quality concepts which were limited only for customer-based criteria have originated various service quality significant factors and models in education field also. The purpose of this paper is to find out the significant service quality factors by using the modified SERVQUAL dimensions and the relationship between PSQ, SAT and Behavioural Intention (BI). For this study independent variables are Assurance, Empathy, Reliability, Responsiveness, and Website Content and dependent variables are Students' PSQ, SAT and BI. The population was undergraduate students who have registered for academic year 2013/2014. The valid sample consisted with 744 students. Data collection were done by using a self-administered questionnaire and survey method. The significant relationships revealed; PSQ with Reliability, Responsiveness and Website Content. Further Students' PSQ with SAT, PSQ with BI and SAT with BI. It is concluded that there is a strong relationship between PSQ and SAT in the ODL environment and a mediated relationship. The variance extracted from the PSQ and SAT were $26 \%$ and BI was $43 \%$. It is recommended to select more SQ variables and should increase the sample size for more accuracy in future study as longitudinal. The implications will contribute theoretically and managerially to formulate practical guidelines and necessary strategies to improve the students' favorable behaviour mediated by the Students' SAT and PSQ.
\end{abstract}

Key Words: Open Distance Learning, Retention, Satisfaction, Perceived Service Quality, Reliability, Responsiveness

\section{INTRODUCTION}

The assess of mediation role of Students' satisfaction between PSQ and BI is very important to deliver a consistent quality service for the students to complete their goals $[1,2,3]$ and their retntion. "Each of the student brings a unique sets of needs to the institution and seeks integration in an individual way" [4, p. 139]. Delivering a quality service among large diversification of students is a challenge for the higher educational institutions. Universities have to face dynamic higher education market changes and accountability for their higher performance standards and fulfilment of the international demands [5]. Education can be consider as a service with multiplicity of students' interactions over time with multiple touch points" [6, p. 1]. Furthermore it can be considered as the only bridge that leads individuals lives towards superior futures and it cannot be separated from human lives [7]. Mainly the education plays a significant role in development of a country and people have to spend higher fee for a better education [7]. "Service Quality can be considered depends on as a critical 
prerequisite for establishing and sustaining, satisfying relationship with valued customers" [8, p. 4]. To build a strong relationship with their existing and potential students [8] and to improve the levels of student satisfaction which would strengthen the institutional reputation. "Quality of service is the key measure of guarantee of organizational competitiveness [9, p. 1] and sustainability for both distance and traditional institutions" [10, p. 2]. In 1985, Parasuraman, Zeithaml, and Berry have conceptualised a gap model for SQ with ten number of dimensions and in 1988 and they have introduced five item scale (SERVQUAL) as a instrument for measuring consumer perceptions for perceived service quality. It was consisted with the dimensions of Assurance, Responsiveness, Empathy, Reliability and Tangibility. They have further instructed that it would need to be customised depending on the requirements of the industry or service organizations. Athiyaman in 1997 has stated that PSQ would influence the student post enrollment communication behaviour [11]. Student satisfaction was defined as "attitude or feeling of a student towards the services provided" [12, p. 12]. Further it has been demarcated as students' perception of educational experiences and values received [13, p. 1]. The concept of service quality is abstract and related to the individual attitudes, his/her satisfaction and experience with the service [10]. Many research studies have revealed a number of factors that led to student dropouts [14,3]. The students those who satisfied only will continue their learning with favorable or loyal behaviour to the institute from their word of mouth or those who unsatisfied may decide to leave the institute with unending work [15].

\section{Problem statement}

Over more than thirty years it has been noted a significant deviation between student enrollment and the graduation rate $[16,17]$. As the general procedure university provides a considerable service to the students from the initial registration to finishing stage. The students' persistence or retention which is connected to students' dropouts have issued a considerable problematic situation. It is not restricted to one university. In the worldwide has aroused this situation and researchers have paved their attention to service quality perspectives and further to students' satisfaction and behavioural intention. As the university provides multiple services in an ODL environment characterized by lack of face to face traditional education system $[18,19]$ it is important to study the association between the student perceived service quality and student satisfaction towards student's retention and completion. Based on literature there is a critical link between student retention and perceived service quality of the ODL environment [20,4]. The quality factors intensely effect the progress of students and favourable perception through quality experience which will to lead to the decision of [20] perseverance. Literature supports for various reasons for this deficiency in ODL environment $[21,22,23,24,25,26,3,27]$. The researchers have empirically proven that the service quality provided by the institution could lead to the student satisfaction or dissatisfaction $[28,29,30,31]$. This research would find the association of Students' PSQ, Students' SAT and Students' BI in ODL in OUSL based on constructs developed by Stodnick \& Rogers, 2008 [32] and Udo, Bagchi, \& Kirs, 2008, 2011 [31, 33].

\section{Objective of the study}

There were three main objectives to achieve with this study;

1. To find the significant relationships between 5 dimensions of modified SERVQUAL and the Students' Perceived Service Quality in ODL in OUSL

2. To find the associations between Students' PSQ, Students' and Students' BI in ODL in OUSL

3. To find the mediation relationship of Students' SAT between Students' PSQ and Students' BI in ODL in OUSL 


\section{Research questions}

Based on the SQ literature, the dimensions of modified SERVQUAL; Assurance, Empathy, Reliability, Responsiveness, and Website Content which could be considered to develop research questions to test the association with Student Perceived Service Quality and Student Satisfaction in ODL $[30,33,31]$

The Research questions of the study are;

1. Is there any association between modified SERVQUAL 5 dimensions and Students' Perceived Service Quality in ODL in OUSL?

2. Is there any association between Students' Perceived Service Quality, Students' Satisfaction and Students' Behavioural Intention in ODL in OUSL?

3. Is there any mediation relationship of Students' Satisfaction between Students' Perceived Service Quality and Students' Behavioural Intention?

\section{Significance of the Study}

The results would provide dynamic information of level of the quality of the service delivered by the institution and how the students perceived their satisfaction. And further as a result of that students' persistence in the further levels until complete their degrees or achieved their planned educational qualifications within a stipulated time from the institution. Furthermore, it would guide the directions of future plans of the institution with students' academic, administrative and policy makers. Development of strategic plans and necessary arrangements would denote high quality service with more beneficial path for the students to success their learning journey. This would be leaded to the student satisfaction, persistence and completion of their registered programmes and ultimate results will be affected for the reputation of the institution.

\section{LITERATURE REVIEW}

The concepts of service quality, satisfaction and behavioural intention are mostly related to the customer service marketing field and gradually it has applied to the educational environment by arguing student as a customer who is received the service for monetary values. Since the education is a lifelong service it is very important to study the facts associated with these three concepts for its sustainability.

\section{Service Quality}

The concept of service quality was defined as "judgment or attitude relating to the overall excellence or superiority of the service" [34,35]. In 2016, Noor, Khalil \& Latif defined it as "a judgment defined by the consumer over a phase of time" [36]. A gap model for Service Quality with 10 number of dimensions was conceptualised in 1985 by Parasuraman, Zeithaml, and Berry as a landmark of the history of the service quality [37]. In 1988 they have introduced SERVQUAL instrument with 5 number of items scale based on consumer perceptions for perceived service quality. It was consisted with the dimensions of Assurance, Responsiveness, Empathy, Reliability, and Tangibility [34]. They have validated the instrument and would not depend on the industry or service organisation. Grönross (1984) [36], based on the "perceived service quality model" which consisted of three dimensions; functional quality, technical quality, and image. The image of the organization considered as the positive or negative customer perception of service quality. Carman (1990) [37] empirically tested SERVQUAL in four different industries and confirmed that dimensions were not extensive enough to cater for the prerequisites of all industries and the wordings and the subject of some individual items need to be changed to adequately support for each service settings. In 1997, Athiyaman empirically tested the linkage between student satisfaction and service quality perceptions for the university education and the results revealed that "perceived quality is a consequence of 
consumer satisfaction" and also a "function of satisfaction " [11]. Further he has attempted to clarify the theoretical definitions of the two variables. "Perceived service quality is defined as an overall evaluation of the goodness or badness of a product or service. In other words, it is an attitude. Consumer satisfaction is similar to attitude, but it is short-term and results from an evaluation of a specific consumption experience" [11, p. 539]. In 2000 by Oldfield \& Baron have investigated the perception of service quality in higher education [40]. They have adopted the performance only SERVQUAL developed by Cronin \& Taylor in 1992 [38]. The three dimensions consisted with the instrument for which are not directly connected with the delivery of the programmes. The "requisite elements", which will fulfil study obligations, "acceptable elements" which will critical to students and "functional elements". Finally, they have concluded that management team must monitor the content and the delivery of the programmes. Furthermore this recommendation was consistent with the Grönroos (1984) [36] "technical quality" [39]. The definition for Perceived service quality was based on Stodnick and Rogers in 2008 as the interaction between student and service Organization. Stodnick \& Rogers, 2008 [32] have applied the SERVQUAL scale to traditional classroom environment as an innovative approach and tried to bridge the gap in the education environment for a well-validated and widely used service quality constructs to evaluate the student perceived service quality. In 2011, Udo, Bagchi and Kirs have empirically presented the modified SERVQUAL constructs by replacing the "Tangibility " dimension with "Web site content " by giving more significance to the e-learning environment in distance education. The empirical research has done by Mason, Mbambo, \& Pillay in 2018 [40] in vocational education and training colleges in South Africa has found only the method of payment showed a medium effect between students' satisfaction and service quality and further explained the poor service quality in their inadequate systems, poor management or staff training with their inappropriate attitudes. In Sri Lankan context by Kajenthiran \& Karunanithy in 2015, have applied the SERVQUAL instrument for the private higher education institutions in Jaffna and found strong positive significant relationships between service quality and students' satisfaction and also with Assurance and Responsiveness [41]. In 2016 Wijesiri has assessed students' satisfaction upon service delivery in the Newish Universities in Sri Lanka. The five (5) constructs were quality of physical facilities, Reliability, Responsiveness, Empathy and Delivery Point Satisfaction shown by Academic \& Administrative staff. All have showed moderate relationship with students' satisfaction and physical facilities has showed the strongest relationship [8].

\section{Service Quality and Student Satisfaction in higher education}

Students' satisfaction can be defined as positive, pride or attractive sentiments which get developed by students towards a university's academic programs [9, p. 828]. Based on Udo, Bagchi and Kirs, 2011, Students' satisfaction could be defined as assessment of the overall student learning experience [31]. In 2008 Stodnick \& Rogers, [32] have applied the same instrument to a traditional classroom for the first time in educational environment in U.S.A and disclosed there were positive relationships between student satisfaction and Empathy, Reliability and Assurance with their course and instructors. As same as in 2008 Hasan, Ilias, Rahman and Razak have evaluated the relationship between SERVQUAL and student's satisfaction in two universities in Malaysia and exposed positive significant relationships with all dimensions [42]. Use the same instrument in the same country in 2011 by Wei and Ramalu have examined the relationship between service quality and student satisfaction and found significant relationships between Students' satisfaction and Responsiveness, Assurance and Empathy [43]. Further in 2014 by Mansori, Vaz and Ismail have revealed that Tangibility, Empathy, and Responsiveness were significant with student satisfaction in private universities and colleges in Malaysia [44]. In 1997 Joseph \& Joseph have examined the determinants of 
business students' perceptions of service quality in education in New Zealand [45] and revealed that career opportunities, programme issues, cost and time, physical aspects, location and other aspects were most significant factors with the service quality. Chakuchichi in 2011 [20] has examined the relation between quality of service delivery, learner support and student retention targeted of current students of the Zimbabwe Open University in all regions and all faculties. Athiyaman in 1997 [11] has empirically proved the importance of service quality in higher education with eight (8) independent variables which could comprise satisfaction or dissatisfaction. In 2018 Trang, Kha, Duyen, \& Linh have found the influential factors SQ factors of Postgraduate students' satisfaction as serviceability, staffs affect and tuition fees in the accounting training institutions in Hanoi Vietnam. [13].

\section{Service Quality, Students' Satisfaction and Students' Behavioural Intention in ODL and their mediation relationships}

Perceived Service Quality and satisfaction are distinct constructs but there is no literature support for clear description of order of the Perceived service quality and satisfaction which construct the better prediction with Behavioural Intention [46, 38, 31]. The student satisfaction was seen to be a major driver of student's loyalty or favourable BI of the students [47]. Udo, Bagchi, \& Kirs (2008) found the direct effect of Web SQ and Behavioural Intention (WSQ) $\rightarrow$ (BI) was positve and significant. The indirect effect of Web Service Quality(WSQ) $\rightarrow$ Customer SAT $\rightarrow$ BI relationship also was found to be positve and significant [33]. Although the direct path exists, the indirect path may be strong enough to retain the customer satisfaction to use the service again and again. The results showed that SAT plays a mediating effect between Web SQ and BI [31]. In 2018 Agbanu, Sonyo, \& Ahiase have identified some factors influencing students' satisfaction in distance education programmes in university of education in Winneba, Ghana [48]. The dependent variable was students' satisfaction and independent variables were administrative support services, course evaluation by students, instructor performance and student instructor interaction. The logistic regression results has revealed that administrative support services, course evaluation by students, instructor's performance and the student instructor interaction have significant relationship with students' satisfaction [48]. In 2015 Sembring has found Responsiveness, assurance, tangible, reliability and empathy were directly influence with satisfaction and career advancement, retention, academic performance, and persistence were influenced by satisfaction in ODL perspectives in Indonesia [49]. In 2012, Mantovani has empirically proved the dimensions of Assurance, Reliability and Website Content have a significant relationship with PSQ in distance education. And also positive significant relationship was found in between Perceived Service Quality and Student Satisfaction [30]. In 2011, Udo, Bagchi and Kirs has proposed a modified SERVQUAL for e-learning environment in distance education with five dimensions: Assurance, Empathy, Responsiveness, Reliability, and Website Content and found a significant relationship with four variables except Reliability with perceived e-learning quality. And also found a positive significant relationship between students' satisfaction and perceptions of e-learning quality and BI [31]. The prevailing literature supports that service quality and students' satisfaction have a significant influence in higher education institutions and cognizant of the dimensions should be determined by the students not by the management of the institutions since they are the major recipients of the services [50]. It could be concluded that extent literature is evident for SERVQUAL constructs, in higher education environment as well as other service organizations and industries. In ODL environment which is mainly based on instructional and technological approach. The applications of service quality aspects and their association are very few in ODL environment. This study would be bridge the gap of this application which would be help to understand more about Students' PSQ and it's dimensions and how it leads towards students' SAT and BI through their mediated significant relationships in ODL environment in Open University of Sri Lanka. 


\section{The conceptual framework}

\section{RESEARCH METHODOLOGY}

The conceptual frame work was mainly based on Mantovani (2012), Stodnick \& Rogers (2008), Udo, Bagchi, \& Kirs,(2008, 2011) [30] [32] [33] [31]. The independent variables were based on modified SERVQUAL five dimensions of Assurance, Empathy, Responsiveness, Reliability and Web Site Content in ODL in OUSL. The dependent variables were Students' Perceived Service Quality, Students' Satisfaction and Students' Behavioural Intention and the constructs would be measured as a direct relationship. The definitions used for this research of the 8 dimensions and number of questions used in the questionnaire for each construct were tabulated in Table1.

Figure 1. Conceptual Model: Relationship between independent and dependent Variables

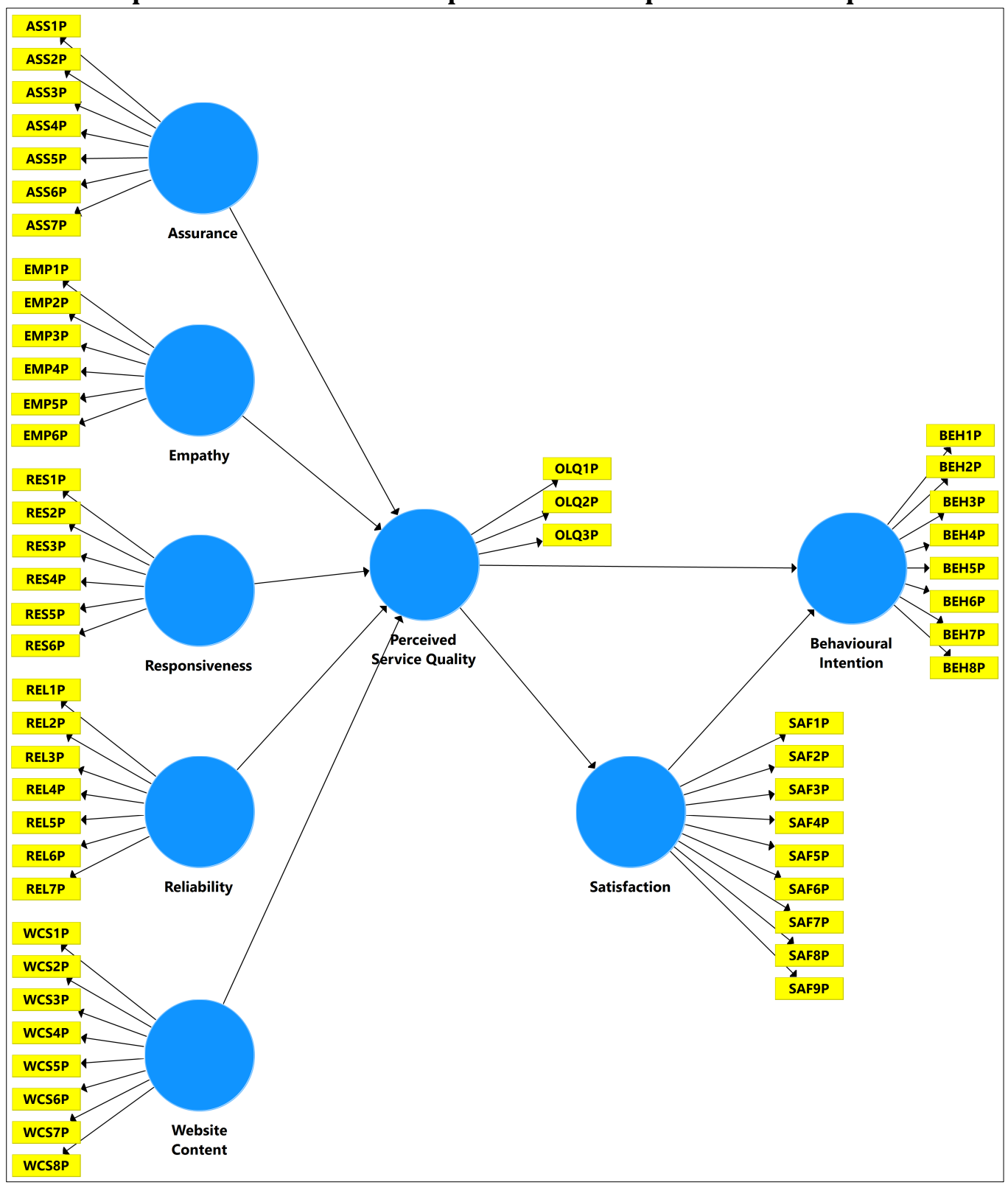


Table 1 Definitions of constructs and number of questions in the questionnaire

\begin{tabular}{|c|c|c|}
\hline Constructs & Definitions of constructs & $\begin{array}{l}\text { Number of } \\
\text { questions }\end{array}$ \\
\hline Assurance & $\begin{array}{l}\text { The knowledge and courtesy of staff and their ability to inspire } \\
\text { trust and confidence for the students }\end{array}$ & (ASS1P-ASS7P) \\
\hline Empathy & $\begin{array}{l}\text { Caring and individualized attention that the university provides to } \\
\text { its students }\end{array}$ & (EMP1P-EMP6P) \\
\hline Responsiveness & Willingness to help students and provide prompt service & (RES1P- RES6P) \\
\hline Reliability & $\begin{array}{l}\text { Ability to perform the promised service dependably and } \\
\text { accurately }\end{array}$ & (REL1P-REL7P) \\
\hline Website Content & $\begin{array}{l}\text { The presentation and layout of information and functions that } \\
\text { capture the overall firm presence and its public image }\end{array}$ & (WCS1P-WCS8P) \\
\hline $\begin{array}{l}\text { Perceived Service } \\
\text { Quality }\end{array}$ & Reflect overall perceptions of Service Quality & (OLQ1P-OLQ3P) \\
\hline Satisfaction & $\begin{array}{l}\text { Assessment of the student's distance learning experience, } \\
\text { including overall pleasure and contentment with the service } \\
\text { received }\end{array}$ & (SAF1P-SAF9P) \\
\hline $\begin{array}{l}\text { Behavioural } \\
\text { Intention }\end{array}$ & $\begin{array}{l}\text { Personal assessment of the value of the programme and Intention } \\
\text { to recommend the program to others and likelihood of enrolling } \\
\text { another program in the future }\end{array}$ & (BEH1P-BEH8P \\
\hline
\end{tabular}

\section{Hypotheses of the study}

The following hypotheses based on the literature were tested in the data analysis against the results.

$\mathbf{H}_{1 \mathrm{~A}}$ : There is an association between Assurance and PSQ in ODL in OUSL

$\mathbf{H}_{1 \mathrm{~B}}$ : There is an association between Empathy and PSQ in ODL in OUSL

$\mathbf{H}_{1 \mathbf{c}}$ : There is an association between Responsiveness and PSQ in ODL in OUSL

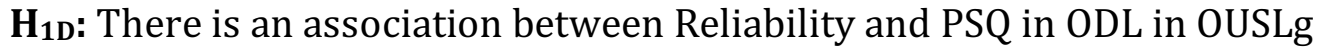

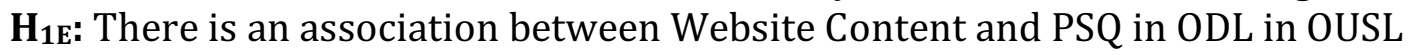

$\mathbf{H}_{2:}$ There is an association between Students' PSQ, Satisfaction and Behavioural Intention in ODL in OUSL

$\mathbf{H}_{3}$ : Students' Satisfaction plays a mediating role between

Perceived Quality and Behavioral Intentions

\section{Research sample}

The target population was mainly based on undergraduate students of the university and who are having more than one year learning experience within the distance learning environment. The target group was selected from the six main Regional Centers (RC) depend on highest student population. Stratified sampling technique [30] was used to derive the sample from the target population of 32,000 undergraduates in academic year 2013-2014. The sample size was determined 760 based on Krejcie and Morgan (1970) [54].

\section{Instrumentation and data collection}

The research instrument which was a self-administered questionnaire mainly based on the literature and minor modifications were made to reflect the ODL environment [50, 55, 56, 47, $30,57,31]$. The questionnaire was mainly consisted with demographic factors and the eight (8) service quality constructs. The measurement scale of the second part of the questionnaire was ordinal (Likert scale 1 through 5; strongly disagree to strongly agree). The primary data collection was done by using the survey method by using a self-administered questionnaire. Data collection was done by random sampling with a minimum interference of the researcher during the day school time specially in the weekends in the regional centers [20,51]. There were 744 valid responses were employed in the analysis and that is $98 \%$ of the estimated sample size. 


\section{Data Analysis}

The accuracy of the measurements are very important for the final results. The measurements could be accomplished through direct and indirect methods. There would be discrepancy with actual and measured known as "measurement error". One way of minimizing the errors would depend on properties of the measurements. The first property of validity which is used to measure " what it was designed to measure" and the second one of reliability which could be interpreted reliably through different settings [52]. Data analysis mainly based on pre and post reliability and validity tests. Post and the pretest of the reliability and validly tests would be done for more robust results [42]. In order to determine the internal consistency of applied modified SERVQUAL scale, reliability analysis was performed and Cronbach's Alpha (CA) coefficients were determined [53]. The Cronbach's alpha values below 0.6 are considered as poor, in 0.7 range are acceptable, and those over 0.8 are good [54]. The Kaiser-Meyer-Olkin (KMO) measure is used to measure the sampling adequacy. "The KMO values greater than 5 is barely acceptable, values between 0.5 - 0.7 are mediocre, values between 0.8 - 0.9 are great and above 0.9 superb" [52]. The Descriptive analysis and inferential statistics will be used for analysis of data. Statistical analysis was carried out using Smart PLS (3.0) Software. The Partial Least Square Structured Equation Method (PLS-SEM) was used due to lack of normality in variable distribution $[55,56,30$, p. 189, 57]. Path models are visually displayed diagrams used to represent the relationships among variables and hypotheses that are examined by using SEM. The constructs that are not directly measured are represented in the path model as circles. The indicators can be measured directly and they are represented by rectangles in the path diagram. Relationships are shown by arrows between the constructs and their indicators. In PLS-SEM, single headed arrows are used as directional relationships. Furthermore, the arrows are considered as "predictive relationships with strong theoretical support that can be interpreted as causal relationships" [56, p. 11]. There are two main elements in the PLS-SEM path model, namely inner model and outer model. The inner model or structural model consists of relationships between constructs. The outer model or measurement model consists of the relationship between constructs and their indicators [56, p. 12]. There are two types of Measurement Models; Reflective and Formative. The measurement model evaluation depends on the relationships between the items and the constructs (Reflective or Formative indicators). The model justification for reflective relationships are indicated by arrows going out from the construct to their items and formative relationships are indicated by arrows coming towards the constructs from the related items. The measurement model generated for this study is a reflective model that the relationships are generated from construct to related items (Figure 1). This model was tested for the outer loadings of the constructs, Construct Reliability and Validity and Discriminant Validity. After confirming the measurement model, the assessment of the structural model will be considered. For the structural model, $\mathrm{R}^{2}$ (explained variance), $\mathrm{f}^{2}$ (effect size), $Q^{2}$ (Predictive relevance) and the size and statistical significance of the structural path coefficients were tested. The fit measures in PLS-SEM are based on variances and focus on the discrepancy between the observed or approximated values of the dependent variables and the values predicted by the model [56].

\section{Profile of the respondents}

\section{RESULTS}

The numbers of valid respondents were 744 rating $98 \%$ of the estimated sample. Most of the respondents were male by representing $64.7 \%$. The center wise representation of respondents rates were; Colombo 56\%, Kandy 22\%, Matara 10\%, Anuradhapura 4\%, Jaffna 4\% and Batticoloa 4\%. The maximum number of respondents were recorded from the age 20-25 of $75 \%$ and $1 \%$ of age Less than $20,18 \%$ of age $26-30,5 \%$ of age $31-40$ and $1 \%$ of age $41-50$ years respectively. 


\section{Descriptive Statistics}

The findings of the descriptive statistics revealed that $67 \%$ of the respondents agreed with Assurance of the ODL and $27 \%$ of them were disagreed. $48 \%$ of them were agreed with the Empathy. 51\%, 47\%, and 65\% of them were agreed with Responsiveness, Reliability and Website Content respectively. Further the students of 76\% were agreed with the Students' PSQ ,76\% were agree with the Students' SAT and 62\% were agreed with Students' BI of the ODL environment.

\section{Pilot test}

The purpose of the pilot test was to clarify about the questions in the questionnaire would have no longer problems when answering by respondents and recording the data. In addition, the assessment of questions could be obtained through the validity and reliability tests. The primary analysis of pilot data would ensure the answers of the investigated questions [52, $\mathrm{p}$. 394].

\section{Pre-testing of questionnaire}

The pilot test was done with 50 numbers of students and tabulated the results in Table 2 with the Cronbach-Alpha (CA) [58] and Kaiser-Meyer-Olkin (KMO) which test for sampling Adequacy. All the values have acquired up to the standard.

Table 2 Pilot test data of Pre-test

\begin{tabular}{|l|c|c|c|c|c|c|c|c|}
\hline & Assurance & Empathy & Responsiveness & Reliability & Web & PSQ & SAT & BI \\
\hline CA & 0.746 & 0.766 & $0 . .816$ & 0.732 & 0.807 & 0.775 & 0.899 & 0.831 \\
\hline KMO value & 0.703 & 0.718 & 0.789 & 0.630 & 0.786 & 0.621 & 0.828 & 0.768 \\
\hline
\end{tabular}

\section{The Assessment of Measurement model (Outer model)}

The minimum requirement of the outer loadings of the constructs in the Measurement model should be greater than or equal to 0.708 and should be statistically significant (Table 3). All outer loadings that are not greater than .708 have to remove from the initial model (Figure1) by examining the effect of the item removal compared with the Composite Reliability (CR) and Average Variance Extracted (AVE). As an established rule of thumb, each construct should explain the variance of at least 50\% [56]. The criteria for internal consistency is Cronbach's Alpha (CA), which provides an estimate of the reliability based on the inter correlations of the observed indicator variables. This is very sensitive to the number of items in the scale [59, $p$. 161]. All of the Cronbach's alpha values for all variables are more than .700 and can be considered as "good" (Table 4). Another, technically more appropriate measurement approach of internal consistency reliability is Composite Reliability (CR). It's minimum threshold value is .700 but should be less than 95 [56, p. 124]. All values in CR have exceed the threshold value and have reached the required level of internal consistency reliability (Table 4). Two ways of evaluating the convergent validity of reflective constructs are the outer loadings of the indicators and AVE. The square value of the size of the outer loadings is called indicator reliability. AVE is equivalent to the communality of a construct. AVE value of 0.50 or higher indicates that the construct has explained half of the variance of its indicators [59, p. 115]. According to Table 3, all AVE values for the constructs are greater than .50. As same as CA and $\mathrm{CR}$, the reliability coefficient $(\rho \mathrm{A})$ should indicate more than 0.70 in exploratory research and more than 0.80 for more advanced stages of research $[64,66,67]$. In Table 3 another reliability coefficient of rho A $(\rho \mathrm{A})$ of each measurement construct is above 0.80 . 
Table 3 The Results summary for Reflective Measurement Model

\begin{tabular}{|c|c|c|c|c|c|c|c|c|}
\hline \multirow[t]{3}{*}{ Construct } & \multirow[t]{3}{*}{ Indicators } & \multirow[t]{3}{*}{$\begin{array}{l}\text { Rho A } \\
(\rho A)\end{array}$} & \multirow{2}{*}{$\begin{array}{l}\text { Convergent Validity } \\
\text { Loadings (L) }\end{array}$} & \multirow{2}{*}{$\begin{array}{l}\text { Internal Consistency } \\
\text { Reliability } \\
\text { **Indicator Reliability } \\
\left(\mathrm{L}^{2}\right)\end{array}$} & \multicolumn{4}{|c|}{$\begin{array}{l}\text { Discriminant } \\
\text { validity }\end{array}$} \\
\hline & & & & & AVE & $\begin{array}{l}\text { Composite } \\
\text { Reliability }\end{array}$ & $\begin{array}{l}\text { Cronbach's } \\
\text { Alpha }\end{array}$ & \\
\hline & & & $>0.70$ & $>0.50$ & $>0.50$ & $0.60-0.90$ & $0.60-0.90$ & $\begin{array}{l}\text { HTMT Confidence } \\
\text { Interval does not } \\
\text { include } 1\end{array}$ \\
\hline Assurance & $\begin{array}{l}\text { ASS1P } \\
\text { ASS2P } \\
\text { ASS3P } \\
\text { ASS4P } \\
\text { ASS5P }\end{array}$ & 0.846 & $\begin{array}{l}0.782 \\
0.822 \\
0.784 \\
0.797 \\
0.711\end{array}$ & $\begin{array}{l}0.611 \\
0.676 \\
0.615 \\
0.635 \\
0.505\end{array}$ & 0.609 & 0.886 & 0.839 & Yes \\
\hline Empathy & $\begin{array}{l}\text { EMP1P } \\
\text { EMP2P } \\
\text { EMP3P } \\
\text { EMP4P } \\
\text { EMP5P } \\
\text { EMP6P }\end{array}$ & 0.882 & $\begin{array}{l}0.791 \\
0.827 \\
0.830 \\
0.699 \\
0.716 \\
0.709\end{array}$ & $\begin{array}{l}0.626 \\
0.685 \\
0.689 \\
0.489 \\
0.512 \\
0.503\end{array}$ & 0.584 & 0.893 & 0.860 & Yes \\
\hline Reliability & $\begin{array}{l}\text { REL1P } \\
\text { REL2P } \\
\text { REL3P } \\
\text { REL4P } \\
\text { REL5P } \\
\text { REL7P }\end{array}$ & 0.834 & $\begin{array}{l}0.805 \\
0.730 \\
0.791 \\
0.700 \\
0.681 \\
0.683\end{array}$ & $\begin{array}{l}0.648 \\
0.533 \\
0.626 \\
0.489 \\
0.464 \\
0.466\end{array}$ & 0.538 & 0.874 & 0.827 & Yes \\
\hline $\begin{array}{l}\text { Responsive } \\
\text { ness }\end{array}$ & $\begin{array}{l}\text { RES1P } \\
\text { RES2P } \\
\text { RES3P } \\
\text { RES4P } \\
\text { RES5P } \\
\text { RES6P }\end{array}$ & 0.876 & $\begin{array}{l}0.794 \\
0.787 \\
0.795 \\
0.776 \\
0.783 \\
0.680\end{array}$ & $\begin{array}{l}0.630 \\
0.619 \\
0.631 \\
0.602 \\
0.613 \\
0.462\end{array}$ & 0.593 & 0.897 & 0.863 & Yes \\
\hline $\begin{array}{l}\text { Website } \\
\text { Content }\end{array}$ & $\begin{array}{l}\text { WCS1P } \\
\text { WCS2P } \\
\text { WCS3P } \\
\text { WCS4P } \\
\text { WCS5P } \\
\text { WCS6P } \\
\text { WCS7P } \\
\text { WCS8P }\end{array}$ & 0.916 & $\begin{array}{l}0.786 \\
0.796 \\
0.817 \\
0.749 \\
0.785 \\
0.790 \\
0.755 \\
0.775\end{array}$ & $\begin{array}{l}0.6181 \\
0.6342 \\
0.6673 \\
0.5614 \\
0.6158 \\
0.6237 \\
0.5699 \\
0.6008\end{array}$ & 0.611 & 0.926 & 0.910 & Yes \\
\hline PSQ & $\begin{array}{l}\text { OLQ1P } \\
\text { OLQ2P } \\
\text { OLQ3P }\end{array}$ & 0.820 & $\begin{array}{l}0.862 \\
0.876 \\
0.817\end{array}$ & $\begin{array}{l}0.743 \\
0.768 \\
0.668\end{array}$ & 0.727 & 0.888 & 0.812 & Yes \\
\hline SAT & $\begin{array}{l}\text { SAF1P } \\
\text { SAF2P } \\
\text { SAF3P } \\
\text { SAF4P } \\
\text { SAF5P } \\
\text { SAF6P } \\
\text { SAF7P } \\
\text { SAF8P } \\
\text { SAF9P }\end{array}$ & 0.892 & $\begin{array}{l}0.771 \\
0.703 \\
0.737 \\
0.709 \\
0.785 \\
0.748 \\
0.734 \\
0.676 \\
0.674\end{array}$ & $\begin{array}{l}0.594 \\
0.495 \\
0.543 \\
0.503 \\
0.616 \\
0.560 \\
0.539 \\
0.457 \\
0.454\end{array}$ & 0.529 & 0.910 & 0.888 & Yes \\
\hline BI & $\begin{array}{l}\text { BEH1P } \\
\text { BEH2P } \\
\text { BEH4P } \\
\text { BEH5P } \\
\text { BEH6P } \\
\text { BEH8P }\end{array}$ & 0.815 & $\begin{array}{l}0.732 \\
0.668 \\
0.691 \\
0.749 \\
0.762 \\
0.676\end{array}$ & $\begin{array}{l}0.535 \\
0.446 \\
0.478 \\
0.561 \\
0.581 \\
0.457\end{array}$ & 0.510 & 0.862 & 0.808 & Yes \\
\hline
\end{tabular}

\section{Discriminant Validity(DV)}

"Discriminant Validity is the extent to which a construct is truly distinct from other constructs by empirical standards [56, p. 115]. First approach of the discriminant validity is cross loadings. In the Table 6 , rows represent the values of indicators and columns represent the constructs. With reference to each and every construct, the values of the indicators show that loadings are exceeding the cross loadings. This indicates the DV has been established. The second approach is the Fornell-Larcker criterion. It compares the square root of the AVE values with the latent variable correlations. The square root of the each construct's AVE values of each 
variable should be greater than its highest correlation with any other construct [56, p. 116]. The Table 4 shows the square root of each construct's AVE values on the diagonal and other non-diagonal values which represent the correlations of other constructs. It can be compared with the same row or with the same column for the establishment of the discriminant validity. The third approach is Heterotrait-Monotrait ratio (HTMT) of the correlations, where the threshold value of 0.85 suggests all HTMT values must be lower than 0.85 . In Table 5 , the HTMT values have reached up to the standard [56, p. 122].

Table 4 Fornell-Larcker Criterion

\begin{tabular}{|l|c|c|c|c|c|c|c|c|}
\hline & Assurance & BI & Empathy & PSQ & Reliability & Responsiveness & Satisfaction & $\begin{array}{c}\text { Website } \\
\text { Content }\end{array}$ \\
\hline Assurance & 0.780 & & & & & & & \\
\hline BI & 0.315 & 0.714 & & & & & & \\
\hline Empathy & 0.565 & 0.293 & 0.764 & & & & & \\
\hline PSQ & 0.221 & 0.423 & 0.223 & 0.852 & & & & \\
\hline Reliability & 0.415 & 0.509 & 0.401 & 0.419 & 0.733 & & & \\
\hline $\begin{array}{l}\text { Responsiven } \\
\text { ess }\end{array}$ & 0.519 & 0.295 & 0.631 & 0.284 & 0.502 & 0.770 & & \\
\hline Satisfaction & 0.334 & 0.667 & 0.259 & 0.511 & 0.563 & 0.314 & 0.727 & 0.630 \\
\hline $\begin{array}{l}\text { Website } \\
\text { Content }\end{array}$ & 0.295 & 0.520 & 0.245 & 0.436 & 0.440 & 0.231 & 0.782 \\
\hline
\end{tabular}

Table 5 Heterotrait - Monotrait Ratio (HTMT)

\begin{tabular}{|l|c|c|c|c|c|c|c|}
\hline & Assurance & BI & Empathy & PSQ & Reliability & Responsiveness & Satisfaction \\
\hline BI & 0.379 & & & & & \\
\hline Empathy & 0.661 & 0.348 & & & & \\
\hline PSQ & 0.261 & 0.518 & 0.250 & & & \\
\hline Reliability & 0.496 & 0.611 & 0.460 & 0.504 & & \\
\hline $\begin{array}{l}\text { Responsive } \\
\text { ness }\end{array}$ & 0.603 & 0.350 & 0.722 & 0.326 & 0.582 & & \\
\hline Satisfaction & 0.385 & 0.772 & 0.283 & 0.592 & 0.650 & 0.342 & \\
\hline $\begin{array}{l}\text { Website } \\
\text { Content }\end{array}$ & 0.330 & 0.595 & 0.271 & 0.494 & 0.505 & 0.249 & 0.697 \\
\hline
\end{tabular}


Table 6 Cross Loadings of the items of th construct

\begin{tabular}{|c|c|c|c|c|c|c|c|c|}
\hline & Assurance & BI & Empathy & PSQ & Reliability & Responsiveness & SAT & $\begin{array}{l}\text { Website } \\
\text { Content }\end{array}$ \\
\hline ASS1P & 0.782 & 0.295 & 0.431 & 0.150 & 0.344 & 0.389 & 0.298 & 0.238 \\
\hline ASS2P & 0.822 & 0.260 & 0.466 & 0.178 & 0.318 & 0.386 & 0.305 & 0.256 \\
\hline ASS3P & 0.784 & 0.191 & 0.403 & 0.196 & 0.293 & 0.409 & 0.226 & 0.170 \\
\hline ASS4P & 0.797 & 0.268 & 0.473 & 0.180 & 0.376 & 0.442 & 0.263 & 0.278 \\
\hline ASS5P & 0.711 & 0.226 & 0.437 & 0.148 & 0.291 & 0.400 & 0.215 & 0.216 \\
\hline BEH1P & 0.321 & 0.732 & 0.209 & 0.322 & 0.420 & 0.186 & 0.582 & 0.437 \\
\hline BEH2P & 0.188 & 0.668 & 0.224 & 0.433 & 0.365 & 0.254 & 0.434 & 0.335 \\
\hline BEH4P & 0.214 & 0.691 & 0.235 & 0.206 & 0.333 & 0.213 & 0.398 & 0.335 \\
\hline BEH5P & 0.202 & 0.749 & 0.199 & 0.268 & 0.364 & 0.196 & 0.526 & 0.412 \\
\hline BEH6P & 0.200 & 0.762 & 0.196 & 0.244 & 0.369 & 0.218 & 0.487 & 0.367 \\
\hline BEH8P & 0.202 & 0.676 & 0.199 & 0.336 & 0.308 & 0.207 & 0.385 & 0.317 \\
\hline EMP1P & 0.548 & 0.306 & 0.791 & 0.216 & 0.403 & 0.527 & 0.315 & 0.272 \\
\hline EMP2P & 0.446 & 0.206 & 0.827 & 0.200 & 0.321 & 0.499 & 0.190 & 0.175 \\
\hline EMP3P & 0.502 & 0.253 & 0.830 & 0.159 & 0.375 & 0.511 & 0.256 & 0.282 \\
\hline EMP4P & 0.430 & 0.223 & 0.699 & 0.089 & 0.281 & 0.424 & 0.192 & 0.248 \\
\hline EMP5P & 0.286 & 0.167 & 0.716 & 0.177 & 0.198 & 0.452 & 0.108 & 0.077 \\
\hline EMP6P & 0.360 & 0.168 & 0.709 & 0.119 & 0.222 & 0.464 & 0.076 & 0.064 \\
\hline OLQ1P & 0.220 & 0.405 & 0.196 & 0.862 & 0.390 & 0.268 & 0.479 & 0.406 \\
\hline OLQ2P & 0.205 & 0.333 & 0.184 & 0.876 & 0.327 & 0.221 & 0.450 & 0.360 \\
\hline OLQ3P & 0.131 & 0.337 & 0.190 & 0.817 & 0.351 & 0.235 & 0.369 & 0.343 \\
\hline REL1P & 0.412 & 0.480 & 0.409 & 0.365 & 0.805 & 0.467 & 0.518 & 0.376 \\
\hline REL2P & 0.300 & 0.333 & 0.260 & 0.320 & 0.730 & 0.355 & 0.371 & 0.216 \\
\hline REL3P & 0.359 & 0.392 & 0.334 & 0.296 & 0.791 & 0.390 & 0.463 & 0.359 \\
\hline REL4P & 0.322 & 0.322 & 0.279 & 0.244 & 0.700 & 0.313 & 0.406 & 0.363 \\
\hline REL5P & 0.179 & 0.310 & 0.198 & 0.309 & 0.681 & 0.338 & 0.304 & 0.272 \\
\hline REL7P & 0.242 & 0.380 & 0.265 & 0.288 & 0.683 & 0.321 & 0.401 & 0.361 \\
\hline RES1P & 0.507 & 0.336 & 0.549 & 0.288 & 0.463 & 0.794 & 0.386 & 0.293 \\
\hline RES2P & 0.421 & 0.218 & 0.502 & 0.197 & 0.388 & 0.787 & 0.245 & 0.188 \\
\hline RES3P & 0.444 & 0.209 & 0.494 & 0.173 & 0.391 & 0.795 & 0.229 & 0.174 \\
\hline RES4P & 0.350 & 0.217 & 0.470 & 0.182 & 0.393 & 0.776 & 0.232 & 0.160 \\
\hline RES5P & 0.398 & 0.189 & 0.507 & 0.193 & 0.376 & 0.783 & 0.187 & 0.152 \\
\hline RES6P & 0.252 & 0.149 & 0.372 & 0.234 & 0.286 & 0.680 & 0.119 & 0.063 \\
\hline SAF1P & 0.311 & 0.525 & 0.304 & 0.467 & 0.457 & 0.309 & 0.771 & 0.505 \\
\hline SAF2P & 0.240 & 0.413 & 0.234 & 0.354 & 0.353 & 0.232 & 0.703 & 0.534 \\
\hline SAF3P & 0.219 & 0.465 & 0.220 & 0.412 & 0.397 & 0.251 & 0.737 & 0.454 \\
\hline SAF4P & 0.201 & 0.463 & 0.250 & 0.395 & 0.418 & 0.268 & 0.709 & 0.488 \\
\hline SAF5P & 0.293 & 0.561 & 0.165 & 0.396 & 0.495 & 0.226 & 0.785 & 0.470 \\
\hline SAF6P & 0.270 & 0.511 & 0.167 & 0.302 & 0.411 & 0.207 & 0.748 & 0.455 \\
\hline SAF7P & 0.239 & 0.487 & 0.154 & 0.403 & 0.423 & 0.244 & 0.734 & 0.447 \\
\hline SAF8P & 0.225 & 0.450 & 0.091 & 0.302 & 0.375 & 0.168 & 0.676 & 0.367 \\
\hline SAF9P & 0.173 & 0.478 & 0.084 & 0.281 & 0.328 & 0.129 & 0.674 & 0.400 \\
\hline WCS1P & 0.356 & 0.502 & 0.238 & 0.376 & 0.455 & 0.259 & 0.580 & 0.786 \\
\hline WCS2P & 0.289 & 0.426 & 0.200 & 0.347 & 0.368 & 0.170 & 0.531 & 0.796 \\
\hline WCS3P & 0.261 & 0.402 & 0.223 & 0.424 & 0.369 & 0.243 & 0.516 & 0.817 \\
\hline WCS4P & 0.206 & 0.381 & 0.203 & 0.367 & 0.283 & 0.197 & 0.418 & 0.749 \\
\hline WCS5P & 0.156 & 0.395 & 0.191 & 0.299 & 0.305 & 0.159 & 0.484 & 0.785 \\
\hline WCS6P & 0.174 & 0.385 & 0.151 & 0.289 & 0.316 & 0.107 & 0.446 & 0.790 \\
\hline WCS7P & 0.169 & 0.360 & 0.111 & 0.282 & 0.306 & 0.122 & 0.457 & 0.755 \\
\hline WCS8P & 0.183 & 0.385 & 0.185 & 0.288 & 0.323 & 0.137 & 0.491 & 0.775 \\
\hline
\end{tabular}

\section{Assessment of Final Structural Model \\ Collinearity Assessment}

The Collinearity assessment is done with Variance Inflation Factor (VIF). The critical level of Collinearity is measured with VIF values which are above 5 [56]. The evaluated VIF values are tabulated in Table 7 (all values less than 2.000). All the VIF values of dependent and independent variables are below the threshold value of 5 and no multicollinearity critical issues with this structural model [57]. Ideally, the VIF values should be close to 3 and lower [57]. 


\begin{tabular}{|l|c|c|c|}
\hline & $\begin{array}{c}\text { Table 7 Collinearity Assessment } \\
\text { Behavioural } \\
\text { Intention }\end{array}$ & $\begin{array}{c}\text { Perceived Service } \\
\text { Quality }\end{array}$ & Satisfaction \\
\hline Assurance & & 1.646 & \\
\hline Behavioural Intention & & 1.913 & \\
\hline Empathy & & 1.000 \\
\hline Perceived Service Quality & 1.353 & 1.604 & \\
\hline Reliability & & 1.967 & \\
\hline Responsiveness & 1.353 & 1.269 & \\
\hline Satisfaction & & & \\
\hline Website Content & & & \\
\hline
\end{tabular}

\section{The Path Coefficients of the structural model}

The path coefficients are the relationships between variables which are related to the significant relationships $(\mathrm{p}<0.05)$ and the supportiveness of the hypotheses (Table 8$)$.

Table 8 Mean, STDEV, T-Values, P-Values of the structural model

\begin{tabular}{|l|c|c|c|c|c|}
\hline & $\begin{array}{c}\text { Original } \\
\text { Sample } \\
(0)\end{array}$ & $\begin{array}{c}\text { Sample } \\
\text { Mean } \\
(\mathrm{M})\end{array}$ & $\begin{array}{c}\text { Standard } \\
\text { Deviation } \\
\text { (STDEV) }\end{array}$ & $\begin{array}{c}\text { T Statistics } \\
(\mid \text { OSTDEV|) }\end{array}$ & $\begin{array}{c}\text { P } \\
\text { Values }\end{array}$ \\
\hline Assurance -> Perceived Service Quality & 0.025 & -0.024 & 0.044 & 0.569 & 0.570 \\
\hline Empathy -> Perceived Service Quality & 0.003 & 0.000 & 0.045 & 0.070 & 0.944 \\
\hline $\begin{array}{l}\text { Perceived Service Quality -> Behavioural } \\
\text { Intention }\end{array}$ & 0.111 & 0.111 & 0.038 & 2.937 & 0.003 \\
\hline Perceived Service Quality -> Satisfaction & 0.511 & 0.512 & 0.033 & 15.384 & 0.000 \\
\hline Reliability -> Perceived Service Quality & 0.239 & 0.239 & 0.044 & 5.414 & 0.000 \\
\hline Responsiveness - Perceived Service Quality & 0.107 & 0.107 & 0.042 & 2.549 & 0.011 \\
\hline Satisfaction -> Behavioural Intention & 0.610 & 0.612 & 0.035 & 17.329 & 0.000 \\
\hline Website Content -> Perceived Service Quality & 0.314 & 0.315 & 0.040 & 7.802 & 0.000 \\
\hline
\end{tabular}

The bootstrapping procedure was applied to identify the significant relationships between the constructs. The standardized values are between +1 and -1 representing larger to smaller respectively and which are closer to 0 are very poor, while path values closer to 1 represent strong relationships. When an empirical t-value is larger than the critical value, it is considered as a significant relationship. The critical values for two-tailed test ( $t$-value) is 1.96 with significant level $5 \%, 2.57$ with significance level $1 \%$ and 1.65 with significance $5 \%$, the p value must be smaller than 0.05 to determine the relationship as a significant at a $5 \%$ level. The table 8 is showed the values of path coefficients(|0), Sample mean (m), Standard deviation (stdev), T statistics ( $\mid \mathrm{o} / \mathrm{stdev})$ and $\mathrm{P}$ values. According to the $\mathrm{T}$ statistics and $\mathrm{P}$ values in the table 8 , all the relationships clearly acquired t-values greater than 1.96 and $p=0.000$ with the 0.05 significance level only consider as significant relationship.

The significant relationships are;

Responsiveness

Reliability

Website Content

Perceived Service Quality

Perceived Service Quality

Satisfaction

$$
\begin{aligned}
& \text {-> Perceived Service Quality } \\
& \text {-> Perceived Service Quality } \\
& \text {-> Perceived Service Quality } \\
& \text {-> Behavioural Intention } \\
& \text {-> Satisfaction } \\
& \text {-> Behavioural Intention }
\end{aligned}
$$

\section{Quality Criteria}

The $\mathrm{R}^{2}$ value which represents the coefficient of determination use to measure the predictive power of the model. The $\mathrm{R}^{2}$ value ranges from 0 to 1 and higher levels represents the high level 
of predictive accuracy $[56,60]$. The $\left(\mathrm{R}^{2}\right)$ for Students' Perceived Service Quality is $0.261(26 \%)$, Satisfaction is $0.261(26 \%)$ and Behavioural Intention is 0.454(45.4\%).

\section{Model fit values}

Two model fit values are Standardized Root Mean Square Residual (SRMR) and Root Mean Square Residual Covariance (RMS theta). The SRMR is defined as the root mean square discrepancy between the observed correlations and the model-implied correlations. The SRMR is an absolute measure of fit, a value of zero indicates perfect fit. With this structural model SRMR is 0.069 and can be assumed the fitness of the model. The RMS theta which relies on covariances. The threshold value for RMStheta is 0.115 and below this value indicate a wellfitting model [61]. With this structural model also RMS theta is 0.124 and can be assumed the fitness of the model [56].

\section{The f Square ( $\left.f^{2}\right)$ values}

The effect size ( $\mathrm{f}^{2}$ value) is used to check the impact on the endogenous construct or whether a predictor latent variable has a weak, medium, or strong effect on the structural model [60]. The guidelines for assessing $\mathrm{f}^{2}$ are the values of 0.02 (small), 0.15 (medium) and 0.35 (large) respectively [56, 62, 62, 63]. According to Table 9 the strongest effects has shown by Website Content to PSQ, PSQ to SAT and SAT to BI.

\begin{tabular}{|c|c|c|c|}
\hline \multicolumn{1}{|c|}{ Table 9 The f Square $\left(\mathbf{f}^{2}\right)$ values } \\
\hline Constructs & PSQ & SAT & BI \\
\hline Assurance & 0.001 & & \\
\hline Empathy & 0.000 & & \\
\hline PSQ & & 0.353 & 0.017 \\
\hline Reliability & 0.048 & & \\
\hline Responsiveness & 0.008 & & \\
\hline Satisfaction & & & 0.505 \\
\hline Website Content & 0.105 & & \\
\hline
\end{tabular}

\section{Construct Cross Validated Redundancy $\left(Q^{2}\right)$}

Table 10 Construct Cross Validated Redundancy

\begin{tabular}{|l|c|c|c|}
\hline & SSO & SSE & $\begin{array}{c}Q^{2}(=1- \\
\text { SSE } / \text { SSO })\end{array}$ \\
\hline Assurance & $3,720.000$ & $3,720.000$ & \\
\hline Behavioural Intention & $4,464.000$ & $3,516.617$ & 0.212 \\
\hline Empathy & $4,464.000$ & $4,464.000$ & \\
\hline Perceived Service Quality & $2,232.000$ & $1,837.691$ & 0.177 \\
\hline Reliability & $4,464.000$ & $4,464.000$ & \\
\hline Responsiveness & $4,464.000$ & $4,464.000$ & \\
\hline Satisfaction & $6,696.000$ & $5,843.938$ & 0.127 \\
\hline Website Content & $5,952.000$ & $5,952.000$ & \\
\hline
\end{tabular}

The blindfolding procedure assesses the predictive relevance with respect to each endogenous construct of the path model. The resulting output of cross validated redundancy estimates are tabulated in Table 10 with SSO (Sum of the Squared Observations), SSE (Sum of Squared Prediction Errors) and the $\mathrm{Q}^{2}$. The $\mathrm{Q}^{2}$ values for all endogenous values must above zero. The highest predictive relevance is showed by BI (0.212) followed by Students' Perceived Service Quality Service Quality $(0.177)$ and Students' Satisfaction is $(0.127)[64,65,56]$. 


\section{TESTING THE MEDIATION EFFECT OF STUDENTS' SATISFACTION BETWEEN STUDENTS' PERCEIVED SERVICE QUALITY AND STUDENTS' BEHAVIOURAL INTENTION}

\begin{tabular}{|l|c|c|c|c|}
\hline \begin{tabular}{|l} 
Table 11 Mediator Analysis \\
Relation ship \\
PSQ $\rightarrow$ BI
\end{tabular} & Path coefficients & $95 \%$ Confidence Interval & t-Value & Significance $(\mathrm{p}<0.05)$ \\
\hline Direct effect & 0.111 & {$[0.036,0.185]$} & 2.937 & 0.003 \\
\hline Indirect effect & 0.312 & {$[0.264,0.365]$} & 11.947 & 0.000 \\
\hline Total effect & 0.423 & {$[0.353,0.489]$} & 11.997 & 0.000 \\
\hline
\end{tabular}

Instead of Sobel test (Sobel, 1982) for mediation effect in the context of Smart PLS, the Bootstrapping procedure was applied through the direct, indirect and total effects. Mediation analysis required a series of analyses of the significance of the direct and indirect effects. Depending on the strength of the relationship, mediation and non-mediation effects can be distinguished (Hair J. F., Hult, Ringle, \& Sarstedt, 2017).

To test the mediation effect of the Students' Satisfaction on the Students' Perceived Service Quality and Behavioural Intention in ODL in OUSL, Table 11 is used. The values of path coefficients, 95\% Bias Corrected Confidence Intervals, $t$ values, and significance $\mathrm{P}$ values $(\mathrm{p}<$ $0.05)$ are included in Table 11.

The bootstrapped results for the direct, indirect and total effects are significant $(\mathrm{p}<0.05)$ since the $95 \%$ bootstrap confidence intervals did not include zero. The direct effect $t$-value is 2.937 with a $p$ value of $(0.111, p=0.003)$, indirect effect $t$-value is 11.947 with a $p$ value of $(0.312$, $\mathrm{p}=0.000$ ).

The direct relationship of Students' PSQ to Satisfaction is significant (path co-efficient is 0.511, $\mathrm{t}=15.384, \mathrm{p}=0.000$ ) and the relationship of Students' Satisfaction to BI is also significant (path co-efficient is $0.610, \mathrm{t}=17.329, \mathrm{p}=0.000$ ).

The direct relationship is showed as weak with compare to others. Therefore, it can be concluded that Students' Satisfaction partially mediates the relationship between Students' PSQ and Students' BI since the both direct and indirect relationships are significant $[57,67]$

To verify the type of the mediation relationship, the product of the direct and indirect relationship $\left(0.0 .111^{*} 0.312=0.003\right)$ is considered. As the direct and indirect relationships are positive, the sign of their product owned is also positive. Therefore, it can be concluded that Student Satisfaction is a complementary mediation of the relationship between PSQ and Students' Behavioural Intention [57].

The factor of Variance Account For (VAF) determined the size of the indirect effect in relation to the total effect (direct effect + Indirect effect) (Table 11).

VAF= Indirect effect $/($ Total effect $)=0.312 / 0.423=0.738(74 \%)$

VAF (74\%) determines the extent of the variance of the Students' Behavioural Intention and is directly explained by the Students' Perceived Service Quality and how much of the variance is explained by the mediated variable of Students' Satisfaction as the indirect relationship [68]. Furthermore, as the VAF is between $80 \%$ and $20 \%$, the relationship is considered as a partial mediation.

*Indirect effect can be obtained by the Bootstrapping Results or product of the two relationships of PSQ to SAT and SAT to BI $\left(0.511^{*} 0.610=0.312\right)$. 


\section{DISCUSSION}

The findings of the study revealed, only three dimensions of SERVQUAL (Reliability, Responsiveness and Website Content) have showed significant positive relationship with Students' Perceived Service Quality. And also very powerful direct significant positive relationship between Students' Perceived Service Quality and Students' Satisfaction and also Students' Satisfaction to Students' Behavioural Intention in ODL. It was further observed that SAT partially mediates by $74 \%$ the impact of SQ on BI. The results showing very favourable output of service quality and there must be a provision for the development of these constructs in ODL environment. These findings are consistent with Mantovani, 2012 a study of distance education environment in Brazil and Udo et al.,2011 the study of distance education e-learning environment in the United States. The finalised model with all significant variables of the study in (Figure 5).

Table 12 Path Coefficients of the finalised model

\begin{tabular}{|l|c|c|c|c|c|}
\hline & $\begin{array}{c}\text { Original } \\
\text { Sample } \\
(\mathrm{O})\end{array}$ & $\begin{array}{c}\text { Sample } \\
\text { Mean } \\
(\mathrm{M})\end{array}$ & $\begin{array}{c}\text { Standard } \\
\text { Deviation } \\
(\text { STDEV })\end{array}$ & $\begin{array}{c}\text { T Statistics } \\
(\mid \mathrm{O} / \text { STDEV|) }\end{array}$ & $\begin{array}{c}\mathrm{P} \\
\text { Values }\end{array}$ \\
\hline $\begin{array}{l}\text { Perceived Service Quality -> Behavioural } \\
\text { Intention }\end{array}$ & 0.111 & 0.111 & 0.037 & 3.006 & 0.003 \\
\hline Perceived Service Quality -> Satisfaction & 0.511 & 0.512 & 0.033 & 15.470 & 0.000 \\
\hline Reliability -> Perceived Service Quality & 0.235 & 0.235 & 0.044 & 5.375 & 0.000 \\
\hline Responsiveness -> Perceived Service Quality & 0.095 & 0.097 & 0.034 & 2.799 & 0.005 \\
\hline Satisfaction -> Behavioural Intention & 0.610 & 0.612 & 0.035 & 17.451 & 0.000 \\
\hline Website Content -> Perceived Service Quality & 0.311 & 0.312 & 0.039 & 7.894 & 0.000 \\
\hline
\end{tabular}

Figure 5 The finalized model for the research

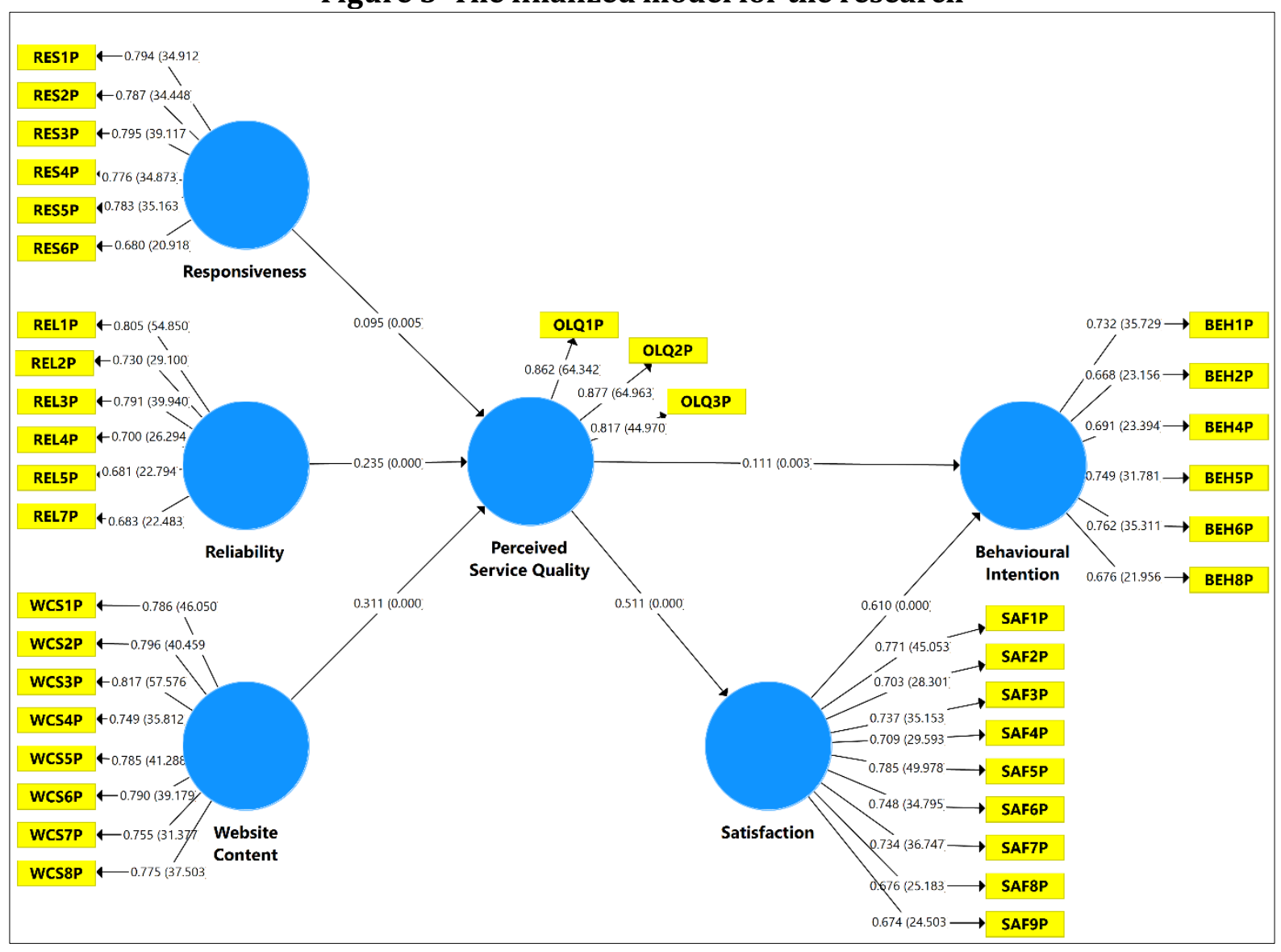

The summary of the Hypotheses; 
Table 13 The summary of the Hypotheses

\begin{tabular}{|c|c|c|c|}
\hline Research Objective & Hypothesis & $\begin{array}{l}\text { Path values \& } \\
\text { Significance } \\
\text { (Figure 5) }\end{array}$ & $\begin{array}{l}\text { Sig. } \\
\text { relation }(\mathrm{Y} / \mathrm{N})\end{array}$ \\
\hline \multirow{5}{*}{$\begin{array}{l}\text { 1.To find the relationships } \\
\text { between } 5 \text { dimensions of } \\
\text { modified SERVQUAL and } \\
\text { Students' Perceived Service } \\
\text { Quality in ODL in OUSL }\end{array}$} & $\begin{array}{l}\mathrm{H}_{1 \mathrm{~A}} \text { : There is an association } \\
\text { between Assurance and PSQ in ODL }\end{array}$ & $0.025(0.570)$ & No \\
\hline & $\begin{array}{l}\mathrm{H}_{1 \mathrm{~B}} \text { : There is an association } \\
\text { between Empathy and PSQ in ODL } \\
\text { in OUSL }\end{array}$ & $0.003(0.944)$ & No \\
\hline & $\begin{array}{l}\mathrm{H}_{1 \mathrm{c}} \text { : There is an association } \\
\text { between Responsiveness and PSQ } \\
\text { in ODL }\end{array}$ & $0.107(0.011)$ & Yes \\
\hline & $\begin{array}{l}\mathrm{H}_{1 D} \text { : There is an association } \\
\text { between Reliability and PSQ in ODL }\end{array}$ & $0.239(0.000)$ & Yes \\
\hline & $\begin{array}{l}\mathrm{H}_{1 \mathrm{E}} \text { : There is an association } \\
\text { between Website Content and PSQ } \\
\text { in ODL }\end{array}$ & $0.314(0.000)$ & Yes \\
\hline \multirow{3}{*}{$\begin{array}{l}\text { 2. To find the associations } \\
\text { between Students' Perceived } \\
\text { Service Quality, Students' } \\
\text { Satisfaction and Students' } \\
\text { Behavioural Intention in ODL } \\
\text { in OUSL }\end{array}$} & $\begin{array}{l}\mathrm{H}_{2 \mathrm{~A}} \text { : There is an association } \\
\text { between Students' PSQ and BI in } \\
\text { ODL }\end{array}$ & $0.111(0.003)$ & Yes \\
\hline & $\begin{array}{l}\mathrm{H}_{2 \mathrm{~B}} \text { : There is an association } \\
\text { between Students' PSQ and SAT in } \\
\text { ODL }\end{array}$ & $0.511(0.000)$ & Yes \\
\hline & $\begin{array}{l}\mathrm{H}_{2 \mathrm{C}} \text { : There is an association } \\
\text { between Students' SAT and BI in } \\
\text { ODL }\end{array}$ & $0.610(0.000)$ & Yes \\
\hline $\begin{array}{l}\text { 3.To find the mediation } \\
\text { relationship of Students' } \\
\text { Satisfaction between } \\
\text { Students' Perceived Service } \\
\text { Quality and Students' } \\
\text { Behavioural Intention in ODL } \\
\text { in OUSL }\end{array}$ & $\begin{array}{l}\mathrm{H}_{3} \text { : Students' Satisfaction plays a } \\
\text { mediating role between Perceived } \\
\text { Quality and Behavioral Intentions }\end{array}$ & $\begin{array}{l}74 \% \text { Partial } \\
\text { Mediation }\end{array}$ & Yes \\
\hline
\end{tabular}

\section{CONCLUSION AND RECOMMENDATIONS}

The results of this research denote precise theoretical insights to the management and comprehensive understanding to broaden the essential features of service quality in ODL. It is evident that service quality is very powerfully influenced Students' Satisfaction and strategic decisions must be applied to enhance the service quality of the institution. To assure the reliable promised service of the academic staff in ODL. The certification of distance education teaching must be compulsory since most of the teachers are familiar with the face to face traditional teaching environment only. Efficient design of web sites with proper multimedia approach facilities which minimize the disadvantages of not having a face to face sessions and to ensure the zero geographical distance, time and cost saving and flexibility of the service. Conduct the same research in all regional centers as longitudinal mode to get the clear picture of the student persistence and add more factors of service quality in different cultures and context around the country. It would be more advantageous to strengthen the Regional Educational Services who is the responsible for delivery part of the education in the university. As the upkeep of the students' knowledge of technology and the interaction of student to technology [67] [68], from the initial stage the Computer Literacy Certificate course must be introduced as a pre-requisite course to register for the any ODL programmes.

\section{References}

T. Dursun, K. Oskaybaş and C. Gökmen, "Comparison of Quality of Service of Distance Education at Universities," The Online Journal of Science and Technology, vol. 4, no. 3, pp. 8-19, 2014. 
T. Dursun, K. Oskayba and C. Gökmen, "The Quality of Service of the Distance Education," Procedia - Social and Behavioral Sciences, vol. 103, p. 1133 - 1151, 2013.

R. Paul and A. Tait, "Open Universities: Past, Present and Future (Editorial)," International Review of Research in Open and Distributed Learning, vol. 20, no. 4, pp. 2-8, October 2019.

S. L. Peterson, P. Kovel-Jarboe and S. A. Schwartz, "Quality Improvement in Higher Education: implications for student retention," Quality in Higher Education, vol. 3, no. 2, pp. 131-141, 1997.

T. Shahsavar and F. Sudzina, "Student satisfaction and loyalty in Denmark: Applicationof EPSI methodology," PLoS $O N E$, vol. 12, no. 12, December 2017.

N. Shaik, S. Lowe and K. Pinegar, "DL-sQUAL: A Multiple-Item Scale for Measuring Service Quality of Online Distance Learning Programs," Online Journal of Distance Learning Administration, vol. 9, no. 2, 2006.

R. Johan and J. Harlan, "Education Nowadays," International Journal of Educational Science and Research, vol. 4, no. 5, pp. 51-56, October 2014.

B. M. Wijesiri, "Assessment of Factors Causing Student Satisfaction upon Service Delivery in the Newish Universities in Sri Lanka," Wayamba Journal of Management, vol. 4, no. 2, pp. 1-8, 2016.

D. Sokoli, A. Koren and C. Gutierrez, "Student'S Perception of Academic Quality: A Review oft the Literature," in International Conference 2018 Technology, Innovation and Industrial Management16-18 May 2018 Naples • Italy, 2018.

D. M. N. M. Ribeiro and M. A. Gouvêa, "Services quality in technology supported education Brazilian case," in 24th Annual POM conference Denver, Colorado.USA: integrating practice in POM research and teaching, 2013.

A. Athiyaman, "Linking student satisfaction and service quality perceptions: the case of university education," European Journal of Marketing, vol. 31, no. 7, pp. 528 - 540, 1997.

R. Chabaya, P. Chadamoyo and C. Chiome, "Student Perceptions of Service Delivery at the Zimbabwe Open University: Masvingo Regional Campus," Zimbabwe International Journal of Open \& Distance Learning, vol. 1, no. 1, pp. 10-17, 2011.

T. T. T. Trang, G. D. Kha, N. T. H. Duyen and T. T. Linh, "Research on Factors Affecting the Postgraduate Students' Satisfaction in the Quality of Training Services in Accounting at the Training Institutions in Hanoi," American Journal of Educational Research, vol. 6, no. 5, pp. 512-518, 2018.

S. S. Khumalo, "Chapter 3 Improving Student Success Rate in Open Distance Learning Settings through the Principle of Constructive Alignment," in Trends in E-learning, 2018, pp. 31-43.

S. Khoo, H. Ha and S. L. McGregor, "Service quality and student/ customer satisfaction in the private tertiary education sector in Singapore," International Journal of Educational Management, vol. 31, no. 4, pp. 430-444, 2017.

tatistical Handbook 2013, Open University of Sri Lanka, 2014, p. 180.

Strategic Management Plan 2015 - 2020, The Open University of Sri Lanka, 2014.

M. G. Moore and G. Kearsley, Distance Education: A Systems View of Online Learning, Third Edition Michael G. Moore and Greg Kearsley, Third Edition ed., M. Kerr and G. Allen, Eds., United States of America: Wadsworth Publishing, 2011, 2011.

O. Simpson, "E-Learning and the Future of Distance Education," 2013.

D. Chakuchichi, "Student Retention as a Function of the Quality of Learner Support in Open and Distance Learning: Students' Perceptions at the Zimbabwe Open University," Zimbabwe International Journal of Open \& Distance Learning , vol. 1, no. 1, pp. 90-98, 2011.

S. A. Ariadurai and R. Manohanthan, "Instructional Strategies in Teaching Engineering at a Distance: Faculty Perspective," International Review of Research in Open and Distance Learning , vol. 9, no. 2, pp. 1-11, June 2008.

T. S. De Zoysa, D. M. Munasinghe, P. Seneviratne and T. Mukunthan, "STUDY ON STUDENT DROPOUT IN ADVANCED CERTIFICATE IN PRE SCHOOL EDUCATION PROGRAMME IN THE OPEN UNIVERSITY OF SRI LANKA," in Annual Academic Session, 2011.

A. G. H. Ismail, "A critical study on factors influencing the student dropout from the educational programmes offered by the Open University of Sri Lanka(Doctoral Thesis)," Faculty of Education ,University of Colombo,Sri Lanka, 1997 August. 
A. G. H. Ismail, "Face-to-Face and Distance Learning in Sri Lanka: Contradictory or Complementary," in Paper presented at the Annual Conference of the Asian Association of Open Universities (4th, Colombo, Sri Lanka, September 17-18, 1991), 1992.

G. Lekamge, G. Ranawake, K. Gunaratne and R. Jayananda, "Student satisfaction with OUSL support services," OUSL Journal, vol. 2, no. 80, 1999.

J. Munro, "The Discourse of Dropout in Distance Education: A Theoretical Analysis.," in Paper presented at the Anual Conference of the Canadian Asociation for the Study of Ault Education (7th, Calgary, Alberta, Canada, May $1988,1987$.

V. Tinto, "Research and Practice of Student Retention: What Next?*," J. College Student Retention, vol. 8, no. 1, pp. 1-19, 2006-2007.

S. Jurkowitsch, C. Vignali and H.-R. Kaufmann, "A STUDENT SATISFACTION MODEL FOR AUSTRIAN HIGHER EDUCATION PROVIDERS CONSIDERING ASPECTS OF MARKETING COMMUNICATIONS," Innovative Marketing, vol. 2, no. 3, pp. 9-23, 2006.

F. N. Machado-Da-Silva, F. d. S. Meirelles, D. Filenga and M. B. Filho, "Student Satisfaction Process in Virtual Learning System: Considerations Based in Information and Service Quality from Brazil'S Experience," Turkish Online Journal of Distance Education-TOJDE, vol. Volume: 15 Number: 3 Article 11, pp. 122-142, July 2014.

D. M. N. Mantovani, "Distance Education on the Stakeholders Perspectives :Student's ,Instructor's and Administrator's Perspectives (Doctoral Dissertation )," University of Sao Paulo, School of Economics,Business and Accounting, Business Department, Business Graduate Program, 2012.

G. J. Udo, K. K. Bagchi and P. J. Kirs, "Using SERVQUAL to assess the quality of e-learning experience," Computers in Human Behavior, vol. 27, p. 1272-1283, 2011.

M. Stodnick and P. Rogers, "Using SERVQUAL to Measure the Quality of the Classroom Experience," Decision Sciences Journal of Innovative Education, vol. 6, no. 1, January 2008.

G. J. Udo, K. K. Bagchi and P. J. Kirs, "Assessing Web Service Quality Dimensions: The E- Servperf Approach," Issues in Information Systems, vol. IX, no. 2, pp. 313-322, 2008.

A. Parasuraman, V. A. Zeithaml and L. L. Berry., "SERVQUAL: A Multiple-Item Scale for Measuring Consumer Perceptions of Service Quality," Journal of Retailing, vol. 64(1) Spring , pp. 12-40, 1988.

D. Yap, G. Timbrell, G. G. Gable and T. Chan, "Towards Global Service Quality Dimentions: an Exploration of Community in Service quality Management across Industries.," in In Proceedings 18th Australasian Conference on Information Systems - ACIS2007, Toowoomba, 2007.

C. Grönroos, "A Service Quality Model and its Marketing Implications," European Journal of Marketing, vol. 18, no. 4, pp. 36 - 44, 1984.

J. Carman, "Consumer perceptions of service quality: an assessment of the SERVQUAL dimensions," Journal of Retailing, vol. 66 , no. 1, pp. 33-55, 1990.

J. J. J. Cronin and S. A. Taylor, "Measuring Service Quality: A Reexamination and Extension," Journal of Marketing, vol. 56, no. 3, pp. 55-68, july 1992.

B. M. Oldfield and S. Baron, "Student perceptions of service quality in a UK university business and management faculty," Quality Assurance in Education, vol. 8, no. 2, pp. 85-95, 2000.

R. Mason, S. Mbambo and M. Pillay, "Service Quality at Technical and Vocational Education and Training Colleges: Perception According yo Demographic Factors," Journal of Technical Education and Training (JTET), vol. 10, no. 1, pp. 15-29, June 2018.

K. Kajenthiran and M. Karunanithy, "Service Quality and Student Satisfaction: A Case Study of Private External Higher Education Institutons in Jaffna, Sri Lanka," Journal of Business Studies, vol. 1, no. 2, pp. 46-64, 2015.

H. F. A. Hasan, A. Ilias, R. A. Rahman and M. Z. A. Razak, "Service Quality and Student Satisfaction: A Case Study at Private Higher Education Institutions," International Business Research, vol. 1, no. 3, pp. 163-175, July 2008.

C. C. Wei and S. S. Ramalu, "Students Satisfaction towards the University: Does Service Quality Matters?," International Journal of Education, vol. 3, no. 2 : E15, pp. 1-15, 2011.

S. Mansori, A. Vaz and Z. M. M. Ismail, "Service Quality, Satisfaction and Student Loyalty in Malaysian Private Education," Asian Social Science, vol. 10, no. 7, pp. 57-66, March 2014.

M. Joseph and B. Joseph, "Service quality in education: a student perspective," Quality Assurance in Education, vol. 5, no. 1, pp. 15-21, 1997. 
R. N. Bolton and J. H. Drew, "A Multi-Stage Model of Customers Assessments of Service Quality and Value,," Journal of Consumer Research, vol. 17 , no. 4, pp. 375-384, 1991.

S. Thomas, "What Drives Student Loyalty in Universities:An Empirical Model from India," International Business Research, vol. 4, no. 2, pp. 183-192, April 2011.

T. Aghamolaei and S. Zare, "Quality gap of educational services in viewpoints of students in Hormozgan University of medical sciences," BMC Medical Education, vol. 8, no. 34, pp. 1-6, 2008.

P. G. Agbanu, E. Sonyo and G. Ahiase, "Examining Factors Influencing Student Satisfaction In Distance Education in Ghana: A Study of the Institute for Educational Development and Extension, University of Education, Winneba," The Online Journal of Distance Education and e-Learning, vol. 6, no. 1, pp. 33-44, January 2018.

M. G. Sembiring, "Validating student satisfaction related to persistence, academic performance, retention and career advancement within ODL perspectives," Open Praxis, vol. 7, no. 4, p. 325-337, October-December 2015.

E. O. Onditi and T. W. Wechuli, "Service Quality and Student Satisfaction in Higher Education Institutions: A Review of Literature," International Journal of Scientific and Research Publications, vol. 7, no. 7, pp. 328-335, July 2017.

D. Murray and G. Howat, "The Relationships among Service Quality,Value, Satisfaction, and Future Intentions of Customers at an Australian Sports and Leisure Centre," Sport Management Review, vol. 5, p. 25-43, 2002.

A. Field, Discovering Statistics Using SPSS (and sex and drugs and rock 'n' roll) Third Edition, SAGE, 2009, p. 856.

Z. Fields and C. Bisschoff, "Comparative analysis of two conceptual frameworks to measure creativity at a university," Problems and Perspectives in Management, vol. 12, no. 3, pp. 46-58, 2014.

U. Sekaran and R. Bougie, Research Methods for Business: A Skill Building Approach (5th Edition) by English, (C) 2000-2015 by John Wiley \& Sons, Inc., or related companies, 2009.

K. Gye-Soo, "Partial Least Squares Structural Equation Modeling (PLS-SEM): An application in Customer Satisfaction Research," International Journal of u- and e-Service, Science and Technology, vol. 9, no. 4, pp. 61-68, 2016.

J. F. Hair, G. T. M. Hult, C. M. Ringle and M. Sarstedt, A Primer on Partial Least Squares Structural Equation Modeling (PLS-SEM) (second Edition ), 2017.

J. F. Hair, J. J. Risher, M. Sarstedt and C. M. Ringle, "When to use and how to report the results of PLS-SEM," European Business Review, vol. 31, no. 1, pp. 2-24, 2019.

J. C. Nunnally, Psychometric theory (2nd ed.)., McGraw-Hill, New York, NY., 1978.

J. F. Hair, W. C. Black, B. J. Babin, R. E. Anderson and R. L. Tatham, Multivariate Data Analysis, vol. Fifth , India: Dorling Kindersley(India ) Pvt Ltd., 2011.

J. Henseler, C. M. Ringle and R. R. Sinkovics, "The Use of Partial Least Squares Path Modeling In International Marketing," New Challenges to International Marketing Advances in International Marketing, vol. 20, p. 277-319, 2009.

J. Henseler, T. K. Dijkstra, M. Sarstedt, C. M. Ringle, A. Diamantopoulos, D. W. Straub, D. J. K. Jr., J. F. Hair, G. T. M. Hult and R. J. Calantone, "Common Beliefs and Reality About PLS: Comments on Ro"nkko" and Evermann (2013)," Organizational Research Methods, vol. 17, no. 2, pp. 182-209, 2014.

A. C. v. Riel, J. Semeijn, W. Hammedi and J. Henseler, "Technology-based service proposal screening and decisionmaking effectiveness," Management Decision, vol. 49, no. 5, pp. 762-783, 2011.

J. Cohen, "Statistical power analysis for the behavioral sciences. (2nd ed.)," Hillsdale, N.J. : L. Erlbaum Associates, 1988.

F. Ali, Y. Zhou, K. Hussain, P. K. Nair and N. A. Ragavan, "Does higher education service quality effect student satisfaction, image and loyalty?," Quality Assurance in Education, vol. 24, no. 1, pp. 70-94, 2016.

U. Banerjee and J. Hine, "Interpreting the influence of urban form on household car travel using partial least squares structural equation modelling: some evidence from Northern Ireland," Transportation Planning and Technology, vol. 39, no. 1, pp. 24-44, 2016.

C. N. Gunawardena, "Social Presence Theory and Implications for Interaction and Collaborative Learning in Computer Conferences," International Journal of Educational Telecommunications, vol. 1, no. 2/3, pp. 147-166, 1995. 
C. N. Gunawardena and M. S. McIsaac, "DISTANCE EDUCATION Chapter 14," pp. 355-395.

R. V. Krejcie and D. W. Morgan, "Determining Sample Size for Research Activities," Educational and Psychological Measurement, vol. 30, pp. 607-610, 1970.

A. Ali and I. Ahmad, "Key Factors for Determining Students' Satisfaction in Distance Learning Courses: A Study of Allama Iqbal Open University," CONTEMPORARY EDUCATIONAL TECHNOLOGY, vol. 2, no. 2, pp. 118-134, 2011.

T. Gruber, S. Fuß, R. Voss and M. Glaeser-Zikuda, "Examining Student Satisfaction with Higher Education Services Using a New Measurement Tool," International Journal of Public Sector Management, vol. 23, no. 2, pp. 105 - 123, 2010.

M. Rahim-Khanli, H. Daneshmandi and A. Choobineh, "The students' viewpoint on the quality gap in educational services," Journal of Advances Medical Education \& Professionalism, vol. 2, no. 3, pp. 114-119, 2014.

"The Anderson-Darling statistic," 2015. [Online]. Available: http://support.minitab.com/en-us/minitab/17/topiclibrary/basic-statistics-and-graphs/introductory-concepts/data-concepts/anderson-darling/. [Accessed 1809 2015].

A. Parasuraman, V. A. Zeithaml and L. L. Berry, "A Conceptual Model of Service Quality and Its Implications for Future Research," The Journal of Marketing, vol. 49, no. 4 ,Autumn, pp. 41-50, 1985.

M. N. M. Noor, M. S. Masuod, A.-M. A. Said, I. F. Kamaruzaman and M. A. Mustafa, "Understanding Consumers and Green Product Purchase Decision in Malaysia: A Structural Equation Modeling - Partial Least Square (SEM-PLS) Approach," Asian Social Science, vol. 12, no. 9, pp. 51-64, 2016.

K. M. Noor, M. A. K. M. Khalil and L. A. Latif, "Harnessing the Power of Service Quality to Attract and Retain Students: an Oum Experience," in Pan Commonwealth Forum, PCF8. , 27-30 November 2016, , KLCC, Kuala Lumpur, 2016.

C. N. Gunawardena and P. L. Duphorne, "Predictors of learner satisfaction in an academic computer conference," Distance Education, vol. 21, no. 1, pp. 101-117, 2000.

C. Gunawardena, "The Challenge of Designing and Evaluating "Interaction" inWeb-Based Distance Education," in WebNet 99 World Conference on the WWW and InternetProceedings (Honolulu, Hawaii, October 24-30, 1999); 1999.

K. Mercy, "Student dropout a cause for concern in ODL: A case of ZOU Midlands Region 2007 to 2013," International Journal of Advanced Research, vol. 2, no. 6, pp. 1115-1121, 2014.

S. Raghavan, M. G. Mohayidin, L. S. Chun, A. S. Juhari and R. Mariapan, "ATTRITION IN ODL: A MACRO PERSPECTIVE FOR REDUCING NON-COMPLETION RATE AMONG LLL LEARNERS," in Seminar Kebangsaan Pembelajaran Sepanjang Hayat, 2014.

M. Obeid, Z. Salleh and M. N. M. Nor, "The Mediating Effect of Job Satisfaction on The Relationship Between Personality Traits and Premature Sign-off," Academy of Accounting and Financial Studies Journal, vol. 21, no. 2, 2017.

F. Olorunniwo and M. K. Hsu, "A typology analysis of service quality, customer satisfaction and behavioral intentions in mass services," Managing Service Quality, vol. 16, no. 2, pp. 106-123, 2006. 